\title{
Componential Analysis of 'Gbá' Verbal Complex and Its Relevance in Second Language Teaching
}

\author{
Eberechukwu Sylvia Nwachi \\ Department of Linguistics, Igbo and Other Nigerian Languages, University of Nigeria, Nsukka, Nigeria \\ Olusanmi Babarinde \\ Department of Linguistics, Igbo and Other Nigerian Languages, University of Nigeria, Nsukka, Nigeria \\ Ndubuisi Ahamefula \\ Department of Linguistics, Igbo and Other Nigerian Languages, University of Nigeria, Nsukka, Nigeria
}

\begin{abstract}
This work examines the componential analysis of the gbá verbal complex in Igbo. It investigates the complex verb gbá in order to find out the basic components of the verb in Igbo thereby arriving at its lexical meaning. The paper adopts the theory of componential analysis for the analysis of data. The data used for the study were elicited through informal interview and the researchers' intuitive knowledge as native speakers. The study found out that ' $g b a{ }^{\prime}$ ' is a verb of movement or motion which results into change of position. This is applicable to all the words that bear the verb root. The distinguishing features that exist among them are equally observed. It is found out that different meanings associated with the word bearing the verb root ' $g b a \dot{~}$ ' is based on the verb that selects the complement thus the word gbá-égwú means 'dance', gbá mgbá 'wrestle' and gbá oso 'run'. It will bring clarity among the meanings of lexemes in the same semantic domain. These findings will be beneficial to curriculum designers by giving them the insight on areas to stress more in teaching second language learners and for documentation.
\end{abstract}

Index Terms - componential analysis, gbá verb, second language teaching, lexeme, meaning

\section{INTRODUCTION}

Language is one of the important aspects of human attributes used purposely as an instrument of expression. It has to do with any means of communication in which thoughts and feelings are symbolized in order to convey meaning. It involves writing, speaking and even gestures, including all types of para-linguistic devices. Crystal (2008) sees language as the concrete act of speaking, writing or signing. He points out that there are varied views of the term language, one of which is in relation to Chomsky's competence and performance. The former focuses attention on the intuitive speakers' ability to utter and comprehend grammatical constructions which are appropriate to the context in which they occur. This is as opposed to performance which is the actual use of language in specific utterances.

There are different aspects of language study which are phonology, morphology, syntax and semantics. Nwaozuzu (2013) holds that even though certain aspects of language studies have attracted expansion in terms of analysis and discoveries, there are others that are yet to lend themselves to concrete definitions, answers and explanations such as semantics. Anagbogu, Mbah and Eme (2010) see semantics as the last level of grammatical analysis that is concerned with the meaning of words, phrases, clauses in language.

Therefore, semantic investigation of language operates at two levels: word level and sentence level (Odo, Nwaozuzu and Mbah, 2015). At word level, semantics explores the relationship between words within a language as a whole. This constitutes the meaning which a word has by virtue of its place in the linguistic system. Such meaning of words that exists at the level of word is studied in lexical semantics which is concerned with word meanings and how these meanings inter-relate with one another. Saeed (2002) believes that meaning is the overall result of all linguistic levels right from the sound level through form and structure level. Changing one phoneme for another, one verb ending for another or one word other for another will produce differences in meaning.

Three types of meaning as distinguished by Finnegan, (2004), are linguistic, social and affective. Linguistic meaning encompasses sense and reference. It refers to a lexeme or larger construction such as sentence to the actual person, object, abstract notion or state to which the lexeme (word) or sentence makes reference. Social meaning is the identification of certain social features of speakers and context from the character of the language employed while affective meaning is the affective connotation that is given to words or utterances (Finnegan, 2004).

A word could represent a complex semantic structure. It comprises smaller units of meaning which are attached differently to derive a different lexeme. The meaning of a word is a complicated structure where different units of meaning have a definite inter-relation (Crystal, 2008). Each semantic unit in a word is not equally important. One or some of them is the dominant semantic element which organizes around itself the remaining ones, these may be more or less important for the meaning of a lexeme (Leech 1983; Lyons, 1995). Corroborating this view, Kahdija (2015) notes 
that componential analysis functions by establishing components to words as lexemes are complexes to be grouped into more simple elements; which can be major or minor elements to the main word. He further observes that in Componential Analysis (CA), meaning usually resides in the interaction between major components; lexical words with high attribution have meaning more than function words. Put differently, meaning is horizontal while in the formal usages meaning is vertical. Words or lexical items with one meaning do hardly undergo componential analysis but can direct the analysis and taken as attribute of meaning.

A word can be analyzed and explained in terms of its ultimate semantic components which help to describe difficult lexical relations, grammatical and syntactical processes. The semantic component of a word is seen as a system of meanings. To some extent, one can define a word by giving to which set it belongs and how it differs considerably from other members of the same set by classifying it into shared and differentiating features. The ultimate semantic features throw more light on how the members of a given set features are related to one another and can be taken to distinguish them from one another. The integration of such features has been called componential analysis (Wardhaugh, 1977; Kreidler 2002).

$\mathrm{CA}$ is one of the three specific frameworks for semantic analysis. The other two are formal semantics and cognitive semantics (Ifeagwazi, 2016). CA is a method adopted in structural semantics to explain the components of a word's meaning. It therefore reveals the essential features by which native speakers of the language distinguish different lexical items in a semantic field or domain (Ottenhelmer, 2006). Language embodies meaning for effective communication, but this intent has been fraught with problems like the use of complex verb in a language without knowledge results in the meaninglessness of the word or grammar to both the native speakers and second language learners. This is applicable to Igbo which is described as a verb language by the early scholars in Igbo grammar like Emenanjo (1975), Ubahakwe (1976), Nwachukwu (1983) and Uwalaka (1984).

The centrality of its function in Igbo language is incontestable and it is a kernel part of speech in Igbo (Igbeaku, Mbah and Nwaozuzu, 2016). Emenanjo (1978) observes that Igbo verb is made up of three mutually obligatory and complementary elements. These obligatory elements are the verb itself, the complement and the bound cognate nouns (BCN). He further observes that in the surface structure, the verb co-occurs with the complement and the BCN or either of them. This implies that every Igbo verb must exist with a nominal element which complements it. In the classification of Igbo verb, Emenanjo (2005), notes that the co-occurring nominal elements is subdivided into five major classes; General Complement Verbs (GCV), Inherent Complement Verbs (ICV), Bound Complement verbs (BCV), prepositional Phrase Complement Verbs (PPCV) and Ergative Complement Verbs (ECV). He goes ahead to say that all Igbo verbs have the BCNs which in a given construction, always occur closely linked to the verb and immediately behind it.

Uwalaka (1984) terms the co-occurrence of the verbs and their bound cognate nouns as verb plus noun complexes. She opines that the verb plus noun complexes be entered in the dictionary. Emenanjo (1978) in his own view maintains that every verb should be entered with its complements or bound cognate nouns in order to bring distinction among the head words. An interesting thing in the views of the above scholars is that they believe that Igbo verbs co-occur with nominal elements which extend the meaning of the verbs. This is what Weinreich (1959) refers to transfer features. Weinreich holds that the features of verbs are transferred to the nouns that follow it. So, the nominal complements are used to derive the meaning of the verb home. This co-occurrence of the Igbo verbs with their nominal elements are not done without selective restrictions. It is the restriction on the combination of senses of words indicated by certain semantic features which they possess, and since in the normal use of language, linguistic forms do not freely co-occur with other linguistics forms (cf. Katz, 1966).

Needs analysis in language teaching and language programme design can be defined as a systematic process which help teachers to collect information and get an accurate and complete picture of their students' needs and preferences. Then they interpret the information collected and make decisions about what to include in their programme based on the interpretations in order to meet the students' needs. This process can be used in response to their academic needs of all the students, for improving their achievements and meeting challenged academic standard. However, this process sometimes does not involve looking at the learners' individual needs but may involve looking at the requirements and expectations of other members involved such as employees, parents, teachers and financial supporters (UKEssays, 2018). It is all about attaining competency and efficiency in communication. Needs analysis is a tool for teaching second language learners. Anyone who learns Igbo and wants to be competent in speaking it must be conversant with Igbo verbs because Igbo language is made up of complex verbs (Igbeaku, Mbah and Nwaozuzu, 2016).

The communicative need of language learners is therefore a major preoccupation of needs analysis. It is a process of finding out the needs for which a learner or group of learners require in a language and arranging the needs according to priorities. Oputa (2011) holds that needs analysis is the most important step in any training process. Thus, needs analysis aids curriculum designers and language teachers to take specific actions on what to do and how to do it in the context of learner-centered instruction. Hence the communicative goals of language learning are to a great extent enshrined in the aims of needs analysis.

This study employs the theory of componential analysis to examine the different meanings of the verbal complex ' $g b a$ ' in Igbo with a view to seeing how its application to lexemes helps in solving meaning problems for the second language learners. According to Uchechukwu (2004), the only verb root in Igbo that is devoid of meaning is ' $g b a ́$ ' and 
still the most productive. The question remains what is the meaning of the ' $g b a$ ' verb root? Is it actually meaningless as propagated by some scholars? Prezi (2015) identifies the meaning of ' $g b a$ ' to be 'run', then if the meaning of the verb ' $g b a ́$ ' is taken to be 'run', how then do we explain the meaning of the following: 'gbá-oso, gbá-mgbá, gbá-nddu, gbáuta, gbá-egbe, gbá-aja, gbá-obara' etc? It is based on this non encompassing notion that this research stands to ascertain the meanings of the verb root ' $g b a$ ' through structural analysis and also consider the implication for the Igbo language teaching. The componential analysis theory will be employed for the analysis of the data. The choice of this theory for the study is due to the fact that it is used to determine the semantic relationship that exists among lexicons of motion verbs and their complements in the same semantic domain. This is a very effective theory for the analysis of the inherent verbs.

\section{THEORETICAL STUDIES}

Since the concept of meaning is very illusive, many analysts in various fields of study have made efforts to see to what extent they could, through some known characteristics of language, grasp the meaning of meaning. In this regard, theories that may help in unraveling the mystery behind the problem posed by defining meaning have been propounded.

\section{A. Theory of Componential Analysis}

The founders of CA are Katz (1972) in the areas of generative grammar and anthropology respectively. Some linguists hold that it appears first in Katz and Fodor (1963) and has been refined in Katz and Postal, (1964) and Ifeagwazi, (2016). This theory tries to give an account of word meaning. The theory of CA is dependent on the principle that the meaning of a lexical item is composed of indivisible semantic components. So, the essential component that form the meaning are elementary units on semantic level. Aitchison (2003) notes that by CA, it is possible to state the smallest indivisible units of lexis or minimal components. The theory holds that the total meaning of a word can be decomposed into its basic components. According to Widyastuti, (2010), 'Components have a distinguishing function and distinguish the meaning of a lexeme from that of semantically related lexemes or accurately they serve to distinguish among the meanings of lexemes in the same semantic domain.'

'It is often seen as a process of breaking down the sense of a word into its minimal distinctive features; that is into components which contrast with other components. It refers to the description of the meaning of words through structured sets of semantic features which are given as 'present, absence or indifferent with reference to feature'. To describe the presence of or absence of a feature, binary rules are used. The symbol [+] means the feature is present while [-] means the feature is absent' (Widyastuti, 2010).

Also, Jackson (1996) and Nida (1975) categorize semantic components into two types. These are: Common component and diagnostic or distinctive component.

A. Common component- This is the primary feature which is commonly shared by every word in the same semantic domain.

B. Diagnostic/distinctive components- These serve to differentiate between the meaning of one word from others in the same domain. Words such as, man, woman, boy, girl and other related words in English could throw light on this illustration. These words belong to the semantic field of 'human' and the relation between them may be presented by the following matrix:

TABLE 1

\begin{tabular}{|c|c|c|c|c|}
\hline Components & $\operatorname{man}$ & woman & boy & girl \\
\hline Human & + & + & + & + \\
\hline Adult & + & + & - & - \\
\hline Male & + & - & + & - \\
\hline
\end{tabular}

In the semantic domain of man, woman, boy and girl, [human] is the common component and they are distinguished by [adult], [male], [female] as the distinctive components. The meanings of the individual items can then be expressed by combinations of these features:

$\begin{array}{ll}\text { Man } & +[\text { human }]+[\text { Adult }]+[\text { Male }] \\ \text { Woman } & +[\text { Human }]+[\text { Adult }]-[\text { Male }] \\ \text { Boy } & +[\text { Human }]-[\text { Adult }]+[\text { Male }] \\ \text { Girl } & +[\text { Human }]-[\text { Adult }]-[\text { Male }]\end{array}$

$\mathrm{CA}$ is a semantic method often used in structural semantics to analyse the structure of the meanings of lexical items. Thus, it shows the significant features by which native speakers of the language distinguish different lexical items in the domain. This is a useful approach to learning another language and understanding a specific semantic domain of ethnography (Leech, 1976). Furthermore, Leech states that CA first evolved in anthropological linguistics as a way of understanding relations between kingship terms. Even though CA was used formerly for kinship terms but it is not 
restricted to the analysis of kinship terms only. It could be applied in many areas of the vocabulary (Kempson, 1977). For instance, the difference between murder and kill can be stated clearly and economically if murder is analysed as having a meaning which is a complex of components representing intention, causation, death, and kill as having the complex of only the components representing causation and death.

Murder [INTENTION], [CAUSATION], [DEATH]

Kill [INTENTION] [CAUSATION], [DEATH].

It could also be used to analyse certain animals. For example:

$\begin{array}{llll}\text { Sheep } & \text { ram } & \text { ewe } & \text { lamb } \\ \text { Horse } & \text { stallion } & \text { mare } & \text { colt } \\ \text { Chicken } & \text { rooster } & \text { hen } & \text { chick }\end{array}$

The item in each column except the first column share features: [Male] for column two [FEMALE] for column three and [YOUNG] for column four. The component common to each row is the general name they are called as the first word. Lehrer (1974) asserts that componential analysis is an aspect of semantic field theory. He corroborates this by explaining that the necessity of looking at a set of words in a carefully delimited area which has basic semantic features in common but whose meanings contrast with each other by virtue of one or more differences in respect to several other features.

Leech (1976) proposes some important principle in componential analysis.

1. The method of componential analysis can be extended to the semantic description of vocabulary as a whole.

2. Semantic statement should be preferable to the empirical evidence of important testing procedures.

3. Semantic comparisons between languages can be made on the basis of common features of meaning (p.56).

Modifications of componential analysis

Componential analysis was modified into Katz's theory by (Katz, 1972). According to Saeed (2003) the two central ideas of the theory are:

1. "Semantic rules have to be recursive for the same reasons as syntactic rules: that the number of possible sentences in a language is very large.

2. The relationship between a sentence and its meaning is not arbitrary and unitary, that is syntactic structure and lexical content interact so that 'John kill Fred' and 'Fred killed John' do not have the same meaning despite containing the same lexical elements"' (p. 74).

For Katz and Fodor (1963), semantic theory has two components: dictionary and projection rules. In dictionary entries each sense of a lexical item has sense feature. That definition is expressed as a set of components. Katz and Fodor (1963) postulate two kinds of components which are semantic markers and distinguishers.

Another modification of componential analysis is done by Talmy, (1985). Talmy distinguishes group of languages with regard to how they express motion events in sentences. He does this by comparing the components of the motion event that each language puts into the verb versus satellite expressions (noun phrases, preposition phrases and adverbial phrases). He used five meaning components to describe lexicalization patterns. The components are: figure, ground, motion, path and manner.

Also, in the presentation of componential analysis meaning components are divided into semantic markers and distinguishers (Fall, 2007). For instance, the word punch is presented as (action) (momentaneous) (make physical contact) [using fist].

Slap. (Action), (Momentaneous) (make physical contact) [using open hand].

Bite. (Action), (Momentaneous) (make physical contact) [holding fold of tissue] [with jaws].

Pinch. (Action), (Momentaneous) (make physical contact) [holding fold of tissue] [With fingers].

According to Nida (1975: 36-38), the meanings of word within a single domain may be related to one another in four ways: contiguous, overlapping, included and complementary. In the analysis of meanings, the contiguous set are important since the meanings in sets are significantly similar, while at the same time they differ considerably in at least one important component. The series of the related meanings of chair, bench, stool and hassock constitute such a set. They belong to the class of pieces of furniture on which people sit but there are certain precise distinctions between them. The meaning of chair contrasts with the meaning of bench. A chair is for one person while a bench is for several persons. Chair also contrasts with stool; a chair has a back and a stool does not. A hassock which is meant for one person has no back nor legs. The componential analysis of the meaning of this series indicated that they are closely related in that they share common components. For instance, they are all objects, countable, artifacts furniture made for sitting. They are also different from one another in at least one ultimate contrastive component.

Nida (1975: 64) states that 'the actual linguistic procedures employed in CA consist of four types: naming, paraphrasing, defining and classifying.' The process of naming in certain respect is similar to reference, though the perspective is somehow different. Reference is described as the relation established between a linguistic form and a referent while naming is the specific act of designating such as referent. The distinctive feature of any semantic unit can be described by employing certain types of paraphrase. For instances, uncle may be paraphrased as my mother's brother or my father's brother. The ultimate contrastive feature of repentance could be he felt sorry for what he had done and determined to change his way of life. Defining is a highly specialized form of paraphrase and it is rarely used in actual language situation. It is an integration of all the various specific paraphrases into one statement based on the distinctive 
components of the particular meaning in question. Classification involves: lumping together those units which have certain unifying feature in common, separating out the units which are distinct from one another and determining the basis for such grouping.

Weinreich (1959) asserts that sets of semantic features for a word may be unordered (clustered) or ordered (configured).

"Cluster: $(a, b)=(b, a)$ while configuration is $(a, b)(b, a)$. Some lexical items may have clusters and configuration in their semantic structural. Ex. (a, b)------(c, d)', (p. 102).

Linking constructions are those which form clusters. Black+dog is a linking construction and forms a cluster (Black, Dog). Non-linking forms are those that yield configurations. In place of projection rule, Weinreich proposes two separate components for the semantic process: the semantic calculator and semantic evaluator. Semantic calculator comprises semantic rules that compute the meaning of a sentence from the meanings of the individual lexical items and the syntactic structures. Semantic evaluator quantitatively measures and computes the deviance of sentences according to the number and kinds of rule violations. A sophisticated evaluator would be sensitive to the stylistic variations, and the measurement of device would vary according to the discourse and the text (cf. Weinreich, 1959).

The areas of strength of CA are: It reveals cultural features which the native speakers of a language distinguish different words in the domain of semantics; it is a good approach to language learning and understanding a specific semantic domain of ethnography; Through componential analysis, we can describe meanings, meaning relationships like entailment, hyponymy, contradiction and the grammatical behaviour of word classes; it is useful for the description of grammatical morphemes and words. This paper, therefore, examines complex verb gbá in Igbo with a view to bringing out both common and distinctive features it has in relation to the complements that attaches to the verb.

\section{B. Needs Analysis}

A needs analysis represents a form of assessing particular linguistic needs of the trainee or group of them. It has not been considered as a research area until the early 1970's, as its importance grew gradually along with expansion of the communicative approach. Shortly, needs analysis experienced a series of continuous development mainly due to the work performed by Richterich (1983) and Mumby (1978). Supporters of the communicative approach quarreled over the choice of the didactical evidence, as it should have been dependent on systematic investigation of the trainees' demand from the target language (as cited in Jeczelewski, 2016).

Linguists acknowledge that it is fundamental to determine wants, needs and lacks of the learner. Needs are those skills which a learner perceives as being relevant to him; wants are a subset of needs, those which a learner put at a high priority given the time available; and the lack is the difference a learner perceives between his present competence in a particular skill and the competence he wishes to achieve (Dickinson, 1991). Some researchers saw a demand to create a clear distinction between the concepts of needs analysis and needs assessment- which are regularly used stating that assessment involves obtaining data, whereas analysis assigning value to that data (Grave,1996). A needs analysis requires compiling information both on the individual or groups of individuals who are to learn a language and on the use to which they are expected to make of it when they have learned it (as cited in Jeczelewski, 2016).

Teachers have intended to meet the needs of their students during their learning, hence the reason for different approaches and their replacement. So, needs analysis is specifically designed for teaching English for specific purposes (ESP) to those who learn English as their second language even though it could be used to teach other languages. Though needs analysis, as we know it today, has gone through many stages, with the publication of Munby's Communicative Syllabus Design in 1978, situations and functions were set within the frame of needs analysis. In his book, Munby introduced 'communication needs processor' (CNP) which is the bases of Munby's approach to needs analysis (cf. UKEssays, 2018). His approach has been used as machinery for identifying learner's needs.

\section{Error Analysis}

An error is a learner's language usage that deviates from or violates the linguistic rules of a target language. Accuracy in addition to complexity and fluency, according to Corder (1981) is identified as one of the three ways of describing learner. Accuracy occurs when the learner's language usage conforms with the linguistic rules of the target language while error occurs when he does not conform to the rules. Those rules may be at different levels: sound, form and structure, meaning, and discourse or sociolinguistics. Error analysis is a technique used to document the systematic errors that appear in learner's language usage. Language teachers who listen to the speeches of their students identify the error first. While native speakers make unsystematic 'performance' errors like slips of the tongue from time to time or shift from formal to informal grammatical patterns in informal contexts, second language learners make errors that native speaker hardly makes. Teachers should ignore mistakes and focus on errors which are the systematic violations of the linguistic rules to which the learner is exposed (cf. Corder, 1981).

\section{EMPIRICAL STUDIES}

Omego, Anyanwu and Onyegbuchulam (2012) conducted a study on Verb-Noun (object) Restriction in Egbughu dialect using the binary features of componential analyses. The verbs break, buy, cut, carry, harvest, put on, open and hold were studied. The componential analysis of the eight verb clusters was given using contrastive, diagnostic and 
supplementary semantic features according to Ndimele, (1999). From their analysis of 'break cluster', five non-nuclear verbs were identified. These are wì̀k, 'tear to break', tùàk 'hit to break', núák 'dislocate to break', and núán 'smash to break'. The semantic features; [+/- breakable], [+/- snappable], [+/- breakable into parts/pieces], [+/- thin object noun], [+/- breakable with hand/leg as instrument], [+/- can be hit against object], [+/- can be hit with finger/toe], have been used to discuss the semantic compatibility relationship between a verb and its accompanying noun object in this cluster.

Two verbs clusters 'buy and cut' were found to have nuclear verb clusters. The two nuclear verb clusters have the capacity to co-occur with a variety of noun objects which have the inherent compatible semantic features of being bought and being cut respectively. So, the research found that verb plays an important role in determining the kind of subject and object that it co-occurs.

Fenglei (2002) studied the componential analysis method. He used this theory to analyse some verbs and nouns in the English language. The aim was to make clear lexical contrasts and similarities. In his analyses, he differentiated between the two verbs 'kill and die'. He concludes that 'kill is not synonymous or the hyponym to 'die'. He equally found out that componential analysis explains words that are more closely related with their meanings with those of others. It is easy to characterize the sense of additional words by adding features.

Koulikova (2006) studied the comparative componential analysis of English and Swedish motion verbs. He used his analysis to explore the relation between motion verbs like come, go, walk, move, proceed and others in English and Swedish. His objective was to establish the common characteristics of the semantic field of motion verbs and also to describe the lexical semantic variants of motion verbs in English and their comparison in Swedish. In this study, Koulikova ascertained that there is something common among these verbs of motion which he called semantic component. He concludes that the semantic component of the verb is that of movement which involves displacement from the person's positions. He identified three types of movement in Swedish. These are: (1) movement as a consequent change of position [ga:rora si]. (2) Movement away from the observer which is interpreted in English by means of the verb go which Jackendoff (1990:89) called verb of external motion. This verb in Swedish is [korsa] meaning 'Cross'- to go over to the other side. (3) Movement towards an observer [komma] which is interpreted in English as 'come'- to move towards someone.

A much more explicit, clear and economical way of characterizing the lexical meaning relations is to use the method of componential analysis which assumes that words do not have unitary meanings but a complex of components. Componential analysis aims at discovering and organizing the semantic components of words. Based on this view, woman would be analysed as having for its meaning a complex of components of [FEMALE], [ADULT], [HUMAN] while spinster as having for its meaning these components, [FEMALE], [ADULT], [HUMAN], [NEVER MARRIED]' (see,

Hadi

Banoori https://www.academia.edu/36574694/CHAPTER_IV_METHODS_OF_SEMANTIC_ANALYSIS_4_1_Componential_ Analysis).

'Kempson (1977) using componential analysis method holds that 'a lexical item P can be defined as hyponym of Q if all the features of $\mathrm{Q}$ are contained in the feature specification of $\mathrm{P}$; and incompatibility can be defined as a relation between a set of items $\mathrm{P}, \mathrm{Q}, \mathrm{R}$, if they share a set of features but differ from each other by one or more contrasting features. For instance, Spinster is a hyponym of woman while it is incompatible with bachelor' (p. 86). Componential Analysis gives the description of words and phrases of a language. The sense of every lexeme can be analysed in terms of a set of more general semantic features, some or all of which will be common to several different lexemes in the vocabulary. Each lexical item is defined in terms of the components' (Lyons, 1977 as cited in (see, Hadi Banoori https://www.academia.edu/36574694/CHAPTER_IV_METHODS_OF_SEMANTIC_ANALYSIS_4_1_Componential_ Analysis).

\section{IV. $G B \dot{A}$ VERB IN IGBO}

'Gbá' verb root is regarded as a complex verb. It attaches itself to many complements to give rise to different meanings. These complements that can follow the ' $g b a$ ' verb root to derive its meaning are known as the clusters of the verb ' $g b a$ '. It is these verb clusters that Uwalaka (1983) and Nwachukwu (1983) call inherent complement verb (ICV). They classified Igbo verbs into inherent complement verbs and non-inherent complement verbs. An inherent complement verb is defined as a morphological subset of verbs which in its citation form consists of a consonant-vowel (CV) root followed by a free noun (or in very few cases a prepositional phrase). The root and its nominal complement form a semantic unit and any dictionary entry which excludes the complement lacks meaning because the complement is the meaning specifying constituent of its verb (Nwachukwu, (1983). For instance, in this verb cluster: 'bu', we have ' $b u$-onu which means literarily carry [bu] and mouth [ọn]. That is carry mouth which means 'fast'. Another complement for the verb cluster ' $b u$ ' is ' $b u-i b u$ ' to get fat. Also in the verb cluster ' $g b a$ ', we have these inherent complements: gbá-egbe 'shoot with gun', gbá-ukwụ 'kick', gbá-moto 'travel in a car', gbá-ndu 'take an oath' and gbáegwu 'dance'.

Igbo verbs are classified into the following; simple verb root; compound verb root; complex verb root and lastly a combination of a simple verb root with a noun or prepositional phrase schematically summarized as [VERB + NP/PP]. It is this last group that is called Inherent Complement Verb structure. Inherent complement forms a single lexeme with its verb root. Also, the inherent complement and its inherent complement verb constitute a single semantic unit and not 
a syntactic unit. To support this assertion, Anyanwu, (2011), holds that the inherent complement in Igbo dialect together with its root constitutes a single semantic unit in the lexicon. It is important to point out that the functional semantic load of an inherent complement verb rests solely on its inherent complement. This is evident from the fact that the verb root which co-occurs with the inherent complement assumes a different meaning if dissociated from its inherent complement (Anyanwu, 2012).

Igbo verbs can also be classified into motion verbs and non- motion verbs. According to Scharlley (2002) for a verb to be a motion verb, there has to be a movement of the whole body involved. The author further adds that the movement can be along a path (run) or at a location (jump). Similarly, Harley (2002) describes motion verbs as those verbs that involve motion or change of position of the body as a whole. In addition to describing motion verbs as those verbs that involve motion or change of position as a whole, Harley (2002) also concludes that English verbs like sit and stand in the active sense are movement verbs while verbs describing facial movements and placing things with the hands (without moving the whole body) are not movement verbs. It is on this note that ' $g b a$ ' verb root is classified under this motion verb (Prezi, 2015).

The essence of analyzing the gbá complex verb is to derive its different underlying meanings and to apply it in communication. The different shades of meaning derived from this complex verb ' $g b a$ ' will help in proper understanding of the word, especially, for clarity, documentation and designing syllabus for teaching those who acquire the Igbo language as their second language.

A. Data Presentation and Analysis
1. ị + gbá + égwú = ìgbá-égwú 'to dance'
2. + gbá + ọ́sọ́ = ịgbá-ọ́sọ́ 'to run'
3. + gbá + ḿgbá = ịgbá ḿgbá 'to wrestle'
4. ị + gbá + mbọ́ = ịgbá mbọ́ 'to struggle'
5. ị + gbá + árá = ìgbá-árá 'to run madness
6. $\dot{i}+$ gbá + égbè = ígbá-égbè 'to shoot
7. ị + gbá + áfá = ígbá-áfá 'divination'
8. $\grave{i}+$ gbá + gbu = igbá-gbu 'to kill with gun'

Phrasal verbs

9. ì + gbá + pụ = ịgbápú 'to run away'

10. ì + gbá + ghárí = ịgághárị 'to run around'

11. i + gbá + tá = ịgbátá 'to run towards something or someone'

12. + gbá + kwú = ìgbá-kwu 'to run towards someone or something'

13. ị + gbá + pụ́tá = ịgbá-pụ́tá 'to rescue'

Gbá is a motion verb. In the linguistic literature motion verbs are defined in various ways. There is neither a simple characteristic, common terminology for this group nor general agreement on how to classify and delimit the verb groups.

The meaning of the verb ' $g b a ́$ ' can be derived by decomposing the word. 'Gbá is an action word or verb of motion which involves physical action. There is movement of the whole body, displacement or shift from the standing point, while the leg makes contact with the ground, and there is target. So, from the above semantic features one can give the verb root "gbá" the semantic components of: (action), (Physical), (displacement), (body movement), (contact), (place of contact), (target), (path). Any other meaning derived from this verb gbá depends on the noun or prepositions that are coming after it which gives it new shades of meaning but still retain these underlying meaning of the verb root.

\section{B. The Verb Root Gbá + the Nouns ósó, Égwú and Ḿgbá}

\section{Illustration 1}

In the phrase 'igbá ósó, gbá égwú, and gbá ḿgbá' have some relationship because of the verb root 'gbá' that is common to the three phrases and equally have a distinguishing features because of the nouns 'ósọ́, égwú ' and ' $m g b a ́$ ' that are attached to it.

Gbá ọ́sọ́ = (Physical action), (displacement), (target), (contact), (body movement), $($ the foot makes contact with the ground),( path taken) [ the raising of foot up and down in a systematic manner],[fast pace movement], [standing erect], [raising of head].

Gbá égwú = (physical action), (target), (contact), (body movement) (the foot makes contact with the ground), (path taken),[systematic raising of foot up and down], [slow movement], [shaking of the body], [undulating manner]

Gba mgba = (physical action), (contact), (target), (body movement), (the foot makes contact with the ground), (path taken), [two opposite force coming in contact], [clinching of fists], [forceful push], [throwing down of the opponent]

In the analysis of the data presented above using Fall (2007) theory which holds that meanings of components are divided into semantic markers represented by the marker bracket (...) and distinguishers represented by the marker square block [...]. The elements within parentheses are called semantic markers while the distinguishers are shown within square brackets. The common sense idea in the theory is that part of a word's meaning is shared with other words but part is unique to that word. Therefore, one will conclude that the distinguishers among gbá ósó, gbá égwú and gbá ḿgbá are: 
Gbá ósó has [the raising of foot up and down in a systematic manner], [fast pace movement], [standing erect], [raising of head].

gbá égwú has: [shaking of the body], [systematic raising of foot up and down] [slow movement], [undulating manner].

Gba mgba on its own has: [two opposite force coming in contact], [clinching of fists], [forceful push], [throwing down of the opponent].

\section{Illustration 2}

There are different types of movement one can deduce from the verb ' $g b a$ ' as a motion verb. There is movement as a consequent change of position. This common feature is found in all the phrases bearing ' $g b a$ ' as their verb root. The movement can either be away from an observer or towards the observer as seen in these phrasal verbs ' $g$ bapu' and 'gbata'.

Gbátá =(Physical action), (displacement), (target), (contact), (body movement), ( the foot makes contact with the ground),( path taken) (the raising of foot up and down in a systematic manner),(fast pace movement), (standing erect), (raising of head), [towards an observer].

Gbápụ́ = (Physical action), (displacement), (target), (contact), $($ body movement $),($ the foot makes contact with the ground),( path taken) (the raising of foot up and down in a systematic manner),(fast pace movement), (standing erect), (raising of head), [away from an observer].

Gbágháríā = (Physical action), (displacement), (target), (contact), (body movement), $($ the foot makes contact with the ground),( path taken) (the raising of foot up and down in a systematic manner),(fast pace movement), (standing erect), (raising of head), [in an unorganized manner].

\section{Illustration 3}

$\mathrm{Gba}+$ ara $=$ gba-ara 'to be mad'

(Physical action), (displacement), (target), (contact), (body movement), ( the foot makes contact with the ground),( path taken) (the raising of foot up and down in a systematic manner),(fast pace movement), [walking in an awkward manner], [no destination/ target]

Gbagbuo 'make a movement and kill (shoot)'

(Physical action), (displacement), (target), (makes contact with the animal), (body movement), [path taken is straight to the target], [fast movement], [hitting the death], [causing death of the target]

Gbámbọ 'struggling to get one's need'

(Physical action), (displacement), (target), (contact), (body movement), (the foot makes contact with the ground), (path taken not straight) (the raising of foot up and down in a systematic manner), (fast pace movement), (standing erect), (raising of head), [towards an observer].

In all these three words, they have semantic relationship because of the verb root ' $g b a$ '. They involve movement of the physical body from place to place. Gba+ara 'movement of someone from place to place while being unfocused'. The person equally talks to herself as she moves. The same thing goes with gbagbuo which literarily means 'something or someone making a movement before killing anything'. In that case, if one analyzes what makes movement before it kills something or someone is nothing but bullet. Therefore, the bullet comes out of the gun and makes a fast move to hit the target which causes the death of that object. This is called 'gbagbuo in Igbo unlike when someone kills something by hitting it with a stick or anything else and it is known as 'kugbuo'. Gbá mbò equally means 'movement from place to place trying to engage in something to earn ones living.'

From the above analysis the actual linguistic procedures employed in analyzing the data are: naming, paraphrasing, defining and classifying.

\section{The Metaphorical Meaning of the Verb Gbá}

In the first illustration, the verb gbá can be translated to mean 'movement which could be fast or slow, round or straight' but that is not the case when attached with the nouns, ósọ́ (run), éqwú (dance) and ḿgbá (wrestle)' respectively. This shows that different meanings can be associated with the verb root ' $g b a$ ' based on the complement that follows it. It is also observed that apart from the concrete meanings of the three examples, the phrases can have metaphorical extensions of their concrete meanings. In which case, Eze n'agba oso ahia means that 'Eze is looking out for customers that will buy his commodities.' Ngozi n'agba ekwu ukwu literarily means 'Ngozi dances with her waist' but means, 'She is wayward' in Owerri dialect, while Nnamdi na-agba m mgba literarily means that 'Nnamdi is wrestling with me' but the underlying meaning is that 'Nnamdi is attacking me.' Also, when someone says that 'O tinyerem na gbagharia' literarily means, 'he made me move in an unorganized manner' while the underlying meaning is that 'He put me into confusion.'

\section{SUMMARY AND CONCLUSION}

The problems of meaning could be approached through different ways. Meaning is related to diverse functions of language and it is chameleonic in nature. The semantic imports of words in a given system are interrelated, overlap. These different meanings are defined (in part) by their relations with other lexemes in the language. When viewed or explained in the same semantic domain or context; words could be grouped based on the shared (positive) and 
differentiating (negative) features. By analysing the semantic sense of a lexeme into its ultimate contrastive features, according to Ndimele (1999), componential analysis of meaning is a useful approach to the study of meaning, especially in explaining the meaning of a word notwithstanding its useful application in linguistics.

With this approach, language users are able to distinguish as appropriate among the meanings of semantically related words in the same semantic domain or context. Though the analysis of a word in terms of its irreducible semantic components that is based on a number of non-shared or contrastive elements may not be sufficient, according to Widyastuti (2010), they define the meaning of a lexical item formed by a number of semantic signs. Through six procedural steps of analysis which are reduced into four basic processes of naming, paraphrasing, defining and classifying, componential analysis has been a useful approach to determine the meaning of a word through its ultimate contrastive elements.

When the meanings of this verb root ' $g b a$ ' are derived, the knowledge of these derivations will help the language teachers to apply and explain it sufficiently in language teaching especially for the benefit of the second language learners L2 for comprehension, competency and communication sake. The lexicographers will equally benefit from the problem-solving efficiency of componential analysis through the development of lexicons and their conceptual meanings.

\section{REFERENCES}

[1] Aitchison, J. (2003). Linguistics. London: Hodder \& Stoughton, Ltd.

[2] Anagbogu, P.N, Mbah, B.M. \& Eme, C.A. (2010). Introduction to linguistics. Awka: Amaka publishers.

[3] Anyanwu, O. (2011). Ibibio predictive copular constructions. Journal of Language and Culture. 2(4), 50-55.

[4] Anyanwu, O. (2012). The syntax and semantics of inherent complement verbs in Igbo. Theory and Practice in Language Studies. 2(8), 1561-1569.

[5] Banoori,H.(https://www.academia.edu/36574694/CHAPTER_IV_METHODS_OF_SEMANTIC_ANALYSIS_4_1_Componen tial_Analysis.

[6] Corder, P. (1981). The significance of learners' errors. International Review of Applied Linguistics 5(4), 161-169.

[7] Crystal, D. (2008). A dictionary of language and phonetics. Oxford: Blackwell Publishing.

[8] Dickinson, R. (1991). Language use in context. Kumasi: Zion Publishers.

[9] Emenanjo, E.N. (1975). Aspects of the Igbo verb. In F.C Ogbalu, and E.N. Emenanjo (eds). Igbo language and culture. (pp 160-173). Ibadan: Oxford University Press.

[10] Emenanjo, E.N. (1978). Elements of modern Igbo grammar. Ibadan: Oxford University Press.

[11] Emenanjo, E.N. (2005). Igbo grammar. Onitsha: African Publishers Ltd.

[12] Fall, B.C. (2007). Semantic analysis: A practical introduction. Oxford: Oxford University Press

[13] Fenglei, H. E. (2002). Principle of componential analysis and Lexical items in language. Journal of Language and Language Use. 15, 93-117.

[14] Finnegan, E. (2004). Language. It's structure and use. USA: Thomson Wadsworth.

[15] Grave, K. (1996). Teachers as course developers. Cambridge: Cambridge CUP.

[16] Harley, H. (2002). Motion verbs and manner. http:/linguistlist.org/issues. Retrieved on 12/5/2019.

[17] Ifeagwazi, P.A. (2016). Componential analysis. In B.M. Mbah, Theories of Linguistics. (pp.154-165). University of Nigeria Press. Nsukka, Enugu.

[18] Igbeaku, B.C, Mbah, B.M \& Nwaozuzu, G.I. (2016). A Sense relational study of verbs of harvesting in Igbo, Nsukka Working Papers in Language, Linguistics and Literature. 4, 28-37.

[19] Jackendoff, R. (1990). Semantic structures. Massachusetts: MIT Press.

[20] Jackson, H (1996), Words and their meaning. New York: Addison Wesley Longman Inc.

[21] Jeczelewski, S. (2016). Needs analysis, course design and evaluation of business English. B. A. Essay. University of Iceland.

[22] Kadija, B (2015). The componential analysis of literary meaning. Reflexion on Praxis, 15, 36-49.

[23] Katz, J.J. (1966). The philosophy of language. New York: Harper and Row.

[24] Katz, J.J. (1972). Semantic theory. New York: Harper and Row.

[25] Katz, J.J \& Fodor, J.A. (1963). The structure of a semantic theory. Cambridge: MIT Press.

[26] Kempson, M (1977). Semantic theory. Cambridge: Cambridge University Press.

[27] Kahdija, R.I. (2015). Meaning in context. Journal of Language and Linguistics. 4(2), 75-89.

[28] Koulikoya, T. (2006). Comparative componential analysis of English and Swedish motion verbs. Linguistics and Language. 13.47-65.

[29] Kreidler, C. (2002). Introducing English semantics. New York: Routledge.

[30] Leech, G. (1983). Semantics. Harmondsworth: Penguin Ltd.

[31] Leech, G. (1976). Semantics. Harmondsworth: Penguin Ltd.

[32] Lehrer, A. (1974). Semantic fields and lexical structures. Amsterdam: North Holland Publishing.

[33] Lyons, J. (1977). Introduction to theoretical linguistics. Cambridge: Cambridge University Press

[34] Lyons, J. (1995). Semantics: An introduction. Cambridge, England: Cambridge University Press.

[35] Mumby, J. (1978). Communicative syllabus design. Cambridge: Cambridge University Press.

[36] Ndimele, O.M (1999) Semantics and the frontiers of communication. Port Harcourt: University of Port Harcourt Press.

[37] Nida, E.A. (1975). Componential analysis of meaning. Belgium: Mouton.

[38] Nwachukwu, P.A. (1983). Reading on the Igbo verb. Onitsha: Africana FEP.

[39] Nwaozuzu, G.I (2013). The Babelist theory of meaning: An inaugural lecture of the University of Nigeria Nsukka, delivered on $28^{\text {th }}$ February. Scholar.google.com.citations. 
[40] Odo, D.C., Nwaozuzu, G.I. \& Mbah, B.M. (2015). Semantic implications of verbs of eating in Nsukka dialect. Nsukka Working Papers in Language, Linguistics and Literature, 3, 66-75.

[41] Omego, C., Anyanwu, O., \& Onyegbuchulam, A. (2012). Verb-noun (object) selectional restriction in Ebughu. Theory and Practice in Language Studies. 2(11), 2226-2238.

[42] Oputa, C. G. (2011). Language needs of computer trainees in Nsukka metropolis. M.A Thesis. University of Nigeria, Nsukka.

[43] Ottenheimer, H.J. (2006). The anthropology of language. Belmont: CA: Thomson Wadsworth.

[44] Prezi, G.O. (2015). Verbs in the Igbo language. A Ph.D Seminar Presentation. Department of Linguistics, University of Nigeria.

[45] Richterich, R. (Ed.) (1983). Introduction to case studies in identifying language needs. Oxford: Pergamon (Council of Europe).

[46] Saeed, J.I. (2002). Semantics. Malden: Blackwell Publishing.

[47] Saeed, J.I. (2003). Semantics. $2^{\text {nd }}$ ed. Oxford: Blackwell.

[48] Scharlley, A. (2002). Motion verbs and manner. http:/linguistlist.org/issues

[49] Talmy, L. (1985). Lexicalisation patterns: Semantic structure in lexical forms. In T. Shopen (Eds). Language typology and syntactic description. (pp.57-149). Cambridge: Cambridge University Press.

[50] Uchechukwu, C. (2004). Igbo verb clusters: The ontology of the -gbá cluster. Valery Solovyev \& Vladimir Polyakow, Text Processing and Cognitive Technologies. 17, 256-269.

[51] Ubahakwe,, E. (1976). On the question of transitivity and intransitivity in Igbo verbs. Odenigbo 1(1), 45-56.

[52] Uwalaka, A. (1983). Some problems relating to Igbo verbal studies. In Nwachukwu, P. A. (ed.) Readings on Igbo verbs (Pp.4257). Onitsha: African Publishers Ltd.

[53] Uwalaka, A. (1984). The syntax and semantics of Igbo verbs: A case grammar analysis. Ph.D Dissertation, University of Ibadan.

[54] UkEssays. (2018).https://www.ukessays.com/essays/english-language/needs-analysis-procedure-in-language-teaching-englishlanguage-essay.php?vref=1.

[55] Wardhaugh, R. (1977). Introduction to linguistics. USA: McGraw-Hill.

[56] Weinreich, M. (1959). History of the Yiddish language: The problems and their implications. Proceedings of the American Philosophical Society. 103(4), 563-570.

[57] Widyastuti, S. (2010). Componential analysis of meaning: Theory and applications. Journal of English and Education. 4(1), 116-128. http://staff.uny.ac.id/sites/default/files/compential\%20analysis\%20of\%20meaning.pdf.

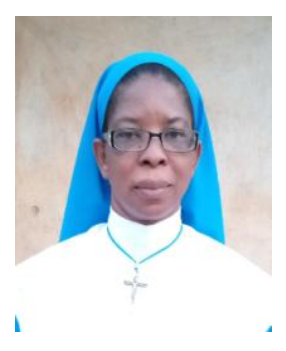

Sr. Sylvia Eberechukwu Nwachi is a finally professed member of Daughters of Divine Love Congregation. She hails from Neke town in Isi-Uzo Local Government Area of Enugu state. She had her Bachelor of Arts (B.A) and Postgraduate Diploma in Education (PGDE) Degrees in Linguistics at the University of Nigeria, Nsukka. She is currently undertaking a Master's Degree in Linguistics in the same university. Her area of speciality is semantics. She speaks the Igbo, English and French languages very fluently. Sr. Sylvia E. Nwachi is a young scholar striving to make some scholarly impacts in academia.

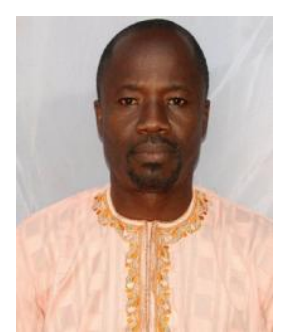

Olusanmi Olasunkanmi Babarinde was born in Gbongan Osun State on 22nd May, 1974. He had his Bachelor of Arts Degree at the University of Ilorin. He obtained M.A and PhD degrees in Linguistics at the University of Nigeria in 2006 and 2012 respectively. His area of specialization is phonology, morphology, and language documentation. He is a postdoctoral student in the Department of Linguistics and Nigerian Languages, University of Nigeria Nsukka. He has a number of scholarly publications to his credit. These include "Computer-assisted language instruction and language learning: Evidence from the English-learning Yoruba talking books 1-5. Language Matters: Studies in the Languages of Africa. 50(2), 100-111"; "Theme, diction and prosodic systems in Yoruba lullabies. International Research in Children's Literature, 12(1). 18-33"; A constraint-based analysis of morphological processes in the Ibibio language. Journal of Language Teaching and Research, 11(2), 242-251.

His professional associations include Linguistic Association of Nigeria, Association for the Promotion of Yoruba Language and Culture, and Modern Language Association of Nigeria.

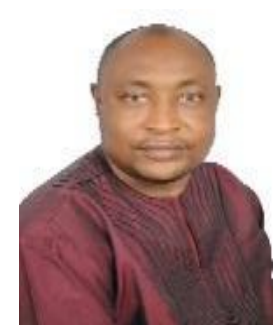

Ndubuisi Ogbonna Ahamefula was born at Isuochi, Abia State Nigeria on $22^{\text {nd }}$ August, 1970. He had his Bachelor of Arts Degree and Master of Arts Degree in Linguistics at the University of Nigeria, Nsukka. Ndubuisi is a doctoral student in the same University. He specializes in applied linguistics and sociolinguistics.

He has a number of publications to his credit including, Contrastive Analysis of consonantal phonemes and Phonotactics of Igbo and Ijo (I o n)". Journal of Linguistic Association of Nigeria (JOLAN), 21(2), 206223. The Igbo Language Need Analysis of Non-Igbo in the University of Nigeria Postgraduate Students: Implication for Curriculum. Research on Humanities and Social Sciences. Vol.3 (14), 57-68.

Mr. Ahamefula is a member of Linguistic Association of Nigeria. 